\title{
SELECTION FOR IMPROVING EGG PRODUCTION IN MANDARAH CHICKENS TO MAXIMIZE THE NET INCOME. 1- CORRELATED RESPONSES, GENETIC PARAMETERS FOR EGG PRODUCTION AND GROWTH TRAITS Abdel-Ghany, F.A. and A.I. Abdel-Ghany Anim. Prod. Inst., Agric. Res. Center, Minist. Agric., Egypt.
}

\begin{abstract}
The aim of the present study was conducted to estimate the correlated response, the genetic parameters (heritability, genetic and phenotypic correlations) of some egg number and growth traits in Mandarah chickens for improving egg number at the first 90 days of laying along three successive generations. Results showed significant differences between selected and control lines as well as among generations. The realized and expected response over two generations were increased body weight at hatch (BW0) $1.23 \mathrm{gm}$ and body weight at four weeks (BW4) $20.27 \mathrm{gm}$, but decreased body weight at 12 weeks of age (BW12) $-15.87,-75.62 \mathrm{gm}$ for male and female. Growth rate was increased at different periods except female (Gr 4-8) decreased. Also, noticed that selection for increasing egg number during first 90 days of laying in Mandarah strain increased egg mass $(232.7 \mathrm{~g})$ and feed conversion $(0.17 \mathrm{~g})$ and reduced age at sexual maturity (- 8.06 days) and average egg weight ($0.47)$.

Estimates of heritability were (0.62 and 0.49$)$ for ASM, and for BWSM (0.41 and 0.21$)$, EN (0.35 and 0.38), EW (0.59 and 0.32), EM (0.39 and 0.36), feed conversion (0.37 and 0.22$)$ for both the selected and control lines, BW0 $(0.13$ and $0.16)$, BW4 (0.32 and 0.31), BW8 (0.58 and 0.53) and BW12 (0.61 and 0.59) for both the selected and control lines, respectively. Genetic correlation in egg number in the selected line were positively associated with BW4 (0.21), BWSM (0.27) and EM (0.79), while, it with BW8 and BW12 weeks of age (-0.35 and -0.24), ASM (-0.39) and EW (-0.41) were negatively associated with egg number. There were low relationships between EN and the other traits studied. Genetic correlations between the other egg number and body weight traits showed a different genetic pattern in both selected and control lines. It could be concluded that selection for increased egg number during the first 90 days of laying in Mandarah strain decreased body weight and growth rate at different age. Heritability estimates based on sire component were higher for the selected line than the control one, which indicated that selection affected the heritability estimates.
\end{abstract}

\section{INTRODUCTION}

Intensive poultry production in Egypt depends not only on commercial hybrids but also on local strains of chickens. During the last four decades some efforts have been done to improve the performance of these local strains through continuous selection under different environmental condition, from these local strains, Mandarah strain. Selection for egg production redacted body weight, as well documented by Kinney (1969). He reported that egg production and body weight in chicken are genetically negatively correlated. The breed or strain variation in the association among the egg production traits was reported by El-Full et al., (2001). 
Egg production is the yield of overall performance of a bird concerning many variables such as egg number, egg weight, egg mass and age at sexual maturity. These variables are correlated with egg production and with each other in the positive or negative trends. Egg production traits are affected by age at sexual maturity. Tawfeek, (1988), Kosba et al, (1997) and Younis and Abd El-Ghany (2004) found that selection for egg number of Silver Montazah chickens increased egg production in association with early sexual maturity, high egg mass and better feed conversion. Realized heritability for egg production traits was reported by Soltan (1991) in Sinai fowl and El-Waradany and Abdou (1993) in Norfa strain. Enab (1982) reported that the genetic correlations between egg number and egg weight were 0.21 and 0.42 in high egg number and high egg size line of White Leghorn, respectively.

Heritability $\left(h^{2}\right)$ of egg production traits have been cited by many researches (Francesch et al. 1997; chen and Tixier-Boichard, 2003) working on exotic strains, in different local strain of chickens Abdou and Enab (1994); Abdou, (2006),Abd el-Ghany 2005,2006, Saleh et al. (2006) and Balat et al.(2008) on local strains. Weight at sexual maturity had different $\left(h^{2}\right)$ estimates, Singh et al.(1986) for exotic strains and Abdel-Halim (1999) and Saleh et al.(2006) using local strains. Also, $\left(h^{2}\right)$ estimates for body weight at different ages (Kosba et al., 2002 and 2006; Abd el-Ghany 2005, 2006, Abdou, 2006 and Saleh et al.2006. Genetic and phenotypic correlations among production and reproduction traits have been studied by Francesch at al. (1997) and Hartmann et al. (2003) working on foreign strains of chickens and those using local strains were (El-Wardany and Abdou 1993; Younis and Abdel-ghany 2004; Abdella 2006 and Saleh et al. 2006).

The present study was conducted to estimate the heritability of egg production and some growth traits for selected and non-selected lines of Mandarah strain, beside estimating the genetic and phenotypic correlations among these traits and correlated response to selection program to developing egg number during four generations.

\section{MATERIALS AND METHODS}

The study was conducted at Sakha Research Station, Kafer El-Sheikh, Animal Production Research Institute, Agriculture Research Center. Two lines of Mandarah strain (Abdel-Gawad, 1981) were used in the present study. Selected line (a total of 3950) and control line (1030) pedigreed unsexed one day chicks hatched over four generations table 1 . Selection was practiced from egg number up to 90 days of age using a family index that took into account the individual performance plus sire family average pullets, and for male were taken according to half-sib mean of egg number.

The chicks were wing banded, weighted at hatch, 4, 8and 12 weeks of age. Feed and water were allowed ad libitum throughout the experiment and the chicks were fed a layer 1 ration containing (19\% crud protein and 2800 $\mathrm{K}$. cal) from hatch to 8 weeks of age, a layer 2 ration containing (15\% CP and $2700 \mathrm{~K}$. cal) from 9 to 20 weeks of age and fed a layer 3 ration containing $(16.5 \% \mathrm{CP}$ and $2750 \mathrm{Kcal})$ up to 54 weeks of age. All cocks vaccinated 
against diseases. Sexes were separated at 8 weeks of age. The pullets were housed in individual laying cages at 20 weeks of age. After 90 days of laying the pullets were housed in breeding been,

\section{Studied traits}

- Body weight at hatch, 4,8 , and 12 weeks of age in grams.

- Growth rate at different periods (0-4), (4-8), (8-12) and (0-8).

- Body weight at age sexual maturity in grams.

- Age at sexually maturity in days (age at first egg).

- Number of eggs in the first 90 days of laying.

- Egg weight, egg mass and feed conversion during the first at the first 90 days of laying.

Table (1): Number of sire, dams and progeny which used in the selected program which used in experimental work.

\begin{tabular}{|c|c|c|c|c|c|c|}
\hline \multirow{2}{*}{ Generation } & \multicolumn{3}{|c|}{ Selected line } & \multicolumn{3}{c|}{ Control line } \\
\cline { 2 - 7 } & Sires & Dams & Progeny & Sires & Dams & Progeny \\
\hline 0 & 20 & 200 & 960 & 9 & 80 & 240 \\
\hline 1 & 22 & 200 & 1000 & 10 & 90 & 280 \\
\hline 2 & 20 & 200 & 980 & 10 & 80 & 260 \\
\hline Total & 62 & 600 & 2940 & 29 & 270 & 780 \\
\hline
\end{tabular}

\section{Statistical analysis:}

Data collected were subjected to ANOVA applying the General Linear Models Procedure of SAS software (SAS, 1990). Duncan's multiple range test (1955) was used to detect the significance of the differences between means of the generations, lines and sexs.

Model: $\quad Y i j k l=u+G i+L j+S k+(G L) i j+(G S) i k+(L S) j k+(G L S) i j k+e ~ i j k l$

Where:

Yijkl $=$ an observation, $u=$ overall mean, $G i=$ the fixed effect of $i^{\text {th }}$ generation, $L j=$ the fixed effect of $j^{\text {th }}$ line, Sk the effect of $k^{\text {th }}$ sex, and (GL)ij, (GS)ik, (LS)jk and (GLS)ijk are the interaction between the main effects studied, and e ijk $=$ random error.

The realized genetic gain per generation was estimated as a deviation of the selected line mean from the control line mean according to the numerator of the following equation after Guill and Washburn, (1974) for estimating realized response.

$$
\mathrm{Rt}=(\mathrm{St}-\mathrm{St}-1)-(\mathrm{Ct}-\mathrm{Ct}-1)
$$

Where: Rt realized gain due to selection in the $t^{\text {th }}$ generation and $S$ and $C$ averages performance of the selected and the control populations.

Heritability from the sire variance component for the studied traits and the phenotypic and genetic correlations between them were estimated according to the equations given by Becker (1985).

\section{RESULTS AND DISCUSSION}

\section{Least-Squares Means and Standard errors:}

Least-square means for body weight at different ages as affected by sex, line and generation are presented in Table (2).The results indected that the generation had a significant effect on body weight at hatch, 4, 8 and 12 
weeks of age. Where body weight at hatch was decreased significantly in the $3^{\text {rd }}$ generation than the $1^{\text {st }}$ and $2^{\text {nd }}$ in selected line, Moreover, chicks for the selected line in the three generations were heavier $(p<0.01)$ compared to the control ones at 4,8 , and 12 weeks of age Also male in the two lines had heavier weight than females at 8 weeks of age. Selection for high body weight at different ages result a positive change for males and females. These results of body weight are agreement with those obtained at different ages of local strains by Abdel-Halim (1999); El-Tahawy (2000); Kosba et al. (2002); Abdel-Ghany (2006) and Balat et al. (2008).

Table (2): Least squares and standard errors of body weight during growing period for the males and females over three generations of selection.

\begin{tabular}{|c|c|c|c|c|c|c|c|}
\hline \multirow{3}{*}{ Gen. } & \multirow{3}{*}{ Line } & \multicolumn{6}{|c|}{ Body weight at different ages } \\
\hline & & \multirow{2}{*}{\begin{tabular}{|c|} 
BW0 \\
Comb.sex \\
\end{tabular}} & \multirow{2}{*}{\begin{tabular}{|c|} 
BW4 \\
Comb.sex \\
\end{tabular}} & \multicolumn{2}{|c|}{ BW8 } & \multicolumn{2}{|c|}{ BW12 } \\
\hline & & & & Male & Female & Male & Female \\
\hline \multirow[t]{3}{*}{ G1 } & S. & \multicolumn{3}{|c|}{\begin{tabular}{|c|c|c|c|}
$34.39 \pm 0.29$ & $222.19 \pm 1.15$ & $569.64 \pm 4.20$
\end{tabular}} & $435.00 \pm 4.70$ & $921.33 \pm 6.56$ & $750.82 \pm 4.93$ \\
\hline & C. & \multicolumn{3}{|c|}{\begin{tabular}{|l|l|l}
$34.11 \pm 0.19$ & $218.89 \pm 1.36$ & $573.88 \pm 7.39$ \\
\end{tabular}} & $471.68 \pm 6.72$ & $918.95 \pm 11.21$ & $740.00 \pm 7.09$ \\
\hline & Av. & \multicolumn{3}{|c|}{$34.24 \pm 0.10221 .35 \pm 0.92570 .72 \pm 3.69$} & $444.03 \pm 4.09$ & $920.72 \pm 5.65$ & \pm 4.47 \\
\hline \multirow[t]{3}{*}{ G2 } & S. & \multicolumn{3}{|c|}{\begin{tabular}{|l|l|l}
$34.76 \pm 0.11$ & $248.44 \pm 1.33$ & $547.59 \pm 3.76$ \\
\end{tabular}} & 443.4 & $880.36 \pm 5.80$ & $739.82 \pm 6.42$ \\
\hline & C. & \multicolumn{3}{|c|}{\begin{tabular}{|l|l|l|}
$33.73 \pm 0.14$ & $230.16 \pm 0.75$ & $579.82 \pm 7.80$ \\
\end{tabular}} & $479.82 \pm 7.80$ & $893.85 \pm 9.86$ & $759.56 \pm 10.52$ \\
\hline & Av. & \multicolumn{3}{|l|}{$34.65 \pm 0.092$} & $453.71 \pm 3.36$ & $883.14 \pm 5.04$ & $745.69 \pm 4.60$ \\
\hline \multirow[t]{3}{*}{ G3 } & S. & \multicolumn{3}{|c|}{\begin{tabular}{|l|l|l}
$35.15 \pm 0.11$ & $260.14 \pm 4.65$ & $551.91 \pm 4.59$ \\
\end{tabular}} & $425.75 \pm 2.74$ & $868.53 \pm 4.00$ & $736.49 \pm 3.88$ \\
\hline & C. & \multicolumn{3}{|c|}{\begin{tabular}{|l|l|l}
$33.83 \pm 0.17$ & $236.07 \pm 2.72$ & $577.39 \pm 5.34$ \\
\end{tabular}} & $483.76 \pm 4.07$ & $926.02 \pm 7.04$ & $801.29 \pm 5.65$ \\
\hline & Av. & \multicolumn{3}{|l|}{34.8} & $445.25 \pm 2.70$ & $882.91 \pm 3.77$ & $752.69 \pm 3.61$ \\
\hline \multicolumn{8}{|c|}{ Significances } \\
\hline \multicolumn{2}{|c|}{ Generation } & * & * & * & & * & * \\
\hline \multicolumn{2}{|c|}{ Line } & * & * & ** & ** & ** & ** \\
\hline \multicolumn{2}{|l|}{ Sex } & & & 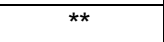 & ** & ** & ** \\
\hline \multicolumn{2}{|l|}{$G^{*} L$} & * & * & * & * & A & \\
\hline
\end{tabular}

G1= First generation G2= Second generation G3=third generation * = significant at 0.05 ${ }^{* *}=$ significant at $0.01 \mathrm{~S}=$ selected line $C=$ control line $A v .=$ Average BW0= Body weight at hatch BW4= Body weight at 4 weeks of age BW8=Body weight at 8 weeks of age BW12= Body weight at 12 weeks of age.

Concerning growth rate at the different periods of age, the differences between generations and lines (Table 3). It was observed that there were significant differences between growth rates during the early period of growth $(0-4),(0-8)$ and $(8-12)$ in two lines, but was decreased significantly $(0,01)$ in the $3^{\text {th }}$ generation than 1 and 2 generations in both lines, chicks for the selected line in three generations were heavier $(p<0.01)$ compared to the control at different ages and males in the two lines had heavier growth rate than females at (4-8), (8-12), Table 3 . The realized correlated response for growth rate was positive at different ages except at (4-8) Table (4).These results of growth rate are agreement with those obtained at different ages by Rizkalla and El-Hossari (2002); Ghanem (2003) and Balat et al.(2008).Which indicated that selection for egg number decreased body weight at 8 weeks of age and growth rate at (4-8). 
Table (3): Least squares and standard errors of growth rate during (012) weeks intervals for the males and females over three generations of selection.

\begin{tabular}{|c|c|c|c|c|c|c|c|c|}
\hline \multirow{3}{*}{ Gen } & \multirow{3}{*}{ Line } & \multicolumn{7}{|c|}{ Body weight at different ages } \\
\hline & & \multirow{2}{*}{\begin{tabular}{|c|} 
Gr(0-4) \\
Comb.sex \\
\end{tabular}} & \multicolumn{2}{|c|}{$\operatorname{Gr}(4-8)$} & \multicolumn{2}{|c|}{ Gr(8-12) } & \multicolumn{2}{|c|}{$\operatorname{Gr}(0-8)$} \\
\hline & & & Male & Fen & Male & Fen & Male & $\mathrm{Fe}$ \\
\hline \multirow[t]{3}{*}{ G1 } & S. & 146.0 & $4.33 \pm 0.91$ & $55.78 \pm$ & 19 & 53.9 & $180.68 \pm 0.17$ & 17 \\
\hline & C. & 145.8 & 96.20 & 90.2 & $.1 \pm$ & & 32 & 172. \\
\hline & Av. & 145.9 & 93.18 & 91.6 & 46 & .79 & 177.1 & 170. \\
\hline \multirow[t]{3}{*}{ G2 } & S. & 150.2 & $71.07 \pm 0.61$ & 60.0 & 46.56 & .63 & 183.22 & 0.15 \\
\hline & C. & 148.8 & 98.88 & 90.5 & 42.69 & .78 & $177.53 \pm 0.30$ & 173.3 \\
\hline & Av. & 149.8 & 85.88 & 85.9 & 45.79 & .51 & $176.17 \pm 0.17$ & $171.27 \pm 0.20$ \\
\hline \multirow[t]{3}{*}{ G3 } & S. & & $68.55 \pm$ & 53.9 & & .60 & $182.62 \pm 0.17$ & $181.54 \pm 0.15$ \\
\hline & C. & & 99.0 & & & & 177.7 & 173.7 \\
\hline & & 150.67 & 778 & & & & \pm 0.17 & $170.45 \pm 0.19$ \\
\hline
\end{tabular}

Significances

\begin{tabular}{|l|c|c|c|c|c|c|c|}
\hline Generation & ${ }^{*}$ & ${ }^{*}$ & ${ }^{*}$ & & ${ }^{*}$ & ${ }^{*}$ & ${ }^{*}$ \\
\hline Line & ${ }^{*}$ & ${ }^{*}$ & ${ }^{* *}$ & ${ }^{* *}$ & ${ }^{* *}$ & ${ }^{* *}$ & ${ }^{* *}$ \\
\hline Sex & & ${ }^{*}$ & ${ }^{* *}$ & ${ }^{* *}$ & ${ }^{* *}$ & ${ }^{* *}$ & ${ }^{* *}$ \\
\hline G*L & ${ }^{*}$ & ${ }^{*}$ & ${ }^{*}$ & ${ }^{*}$ & ${ }^{*}$ & ${ }^{*}$ & ${ }^{*}$ \\
\hline
\end{tabular}

G1= First generation G2= Second generation G3=third generation

${ }^{*}=$ significant at $0.05{ }^{* *}=$ significant at $0.01 \mathrm{~S}=$ selected line

$C=$ control line $A v .=$ Average $\operatorname{Gr}(0-4)=$ growth rate during ( hatch - 4weeks)

$\operatorname{Gr}(4-8)=$ growth rate during $(4-8$ weeks) $\operatorname{Gr}(8-12)=$ growth rate during ( 8-12weeks)

$\operatorname{Gr}(0-8)=$ growth rate during ( hatch -8 weeks)

The means of age at sexual maturity (days) for different generations, are presented in Table (4). Were 170.19, 167.77 and 161.63 days for the selected line and $175.93,174.45$ and 175.43 for the control line, respectively. The selected line pullets matured earlier than of the control line. Decreasing sexual maturity of selected line during the 2,3 generations reflected the effect of selection for high egg number. El-Wardany et al.(1992);Abdel-Halim (1999); Younis and Abdel-Ghany (2004), Abdel-Ghany(2006) and Aly et al. (2010).

Body weight at sexual maturity for selected line had negative correlation with egg number at first 90 days of laying, Table 4. Significant differences were found between selected line and control lines as well as between generations. El-Wardany et al.(1992);Abdel-Halim (1999); Younis and Abdel-Ghany (2004), Abdel-Ghany(2006), Average egg weight during 90 days of laying for selected line had negative correlation with egg number at first 90 days of lying. Significant differences were found between selected line and control lines as well as between generations. Egg mass during 90 days of laying for selected line had positive correlation with egg number at first 90 days of laying. Significant differences were found between selected line and control lines as well as between generations. These results are in agreed with those obtained by El-Wardany et al.(1992);Abdel-Halim (1999); Younis and Abdel-Ghany (2004), Abdel-Ghany(2006) and Aly et al. (2010). Feed conversion (feed intake, $\mathrm{kg} /$ Egg mass, $\mathrm{kg}$ ) at first 90 days of lying affected by line and generation are presented in Table (4).

During first 90 days of lying in Table (4). Significant differences were found between selected line and control lines as well as between 
generations. These results were closely in agreement to those reported by Saleh et al. (1994), Younis and Abdel-Ghany (2004), Abdel-Ghany (2006) and Aly et al. (2010). Negative genetic and phenotypic correlations were found between egg number and age at sexual maturity and feed conversion while positive correlations were found between egg number and egg weight and egg mass

Table (4): Least squares means and standard errors of body weight at sexual maturity, age at sexual maturity, ( egg number, egg weight, egg mass and feed conversion) at 90 days of laying in Mandarah strain selected and control over $\mathbf{4}$ generations.

\begin{tabular}{|c|c|c|c|c|c|c|c|}
\hline tions & Line & ASM & BWSM & EN & EW & EM & F.conv. \\
\hline \multirow[t]{2}{*}{ G1 } & Selected & $0.19 \pm 0.89$ & $1500.65 \pm 4.65$ & $45.59 \pm 0.59$ & $48.59 \pm 0.09$ & $2219.21 \pm 14.89$ & $5.02 \pm 0.07$ \\
\hline & & 175.93 & $1528.25 \pm 7.35$ & $37.45 \pm 0.54$ & $49.63 \pm 0.13$ & 1861.64 & $6.85 \pm 0.13$ \\
\hline \multicolumn{2}{|l|}{ Overall mean } & 171.9 & & $43.50 \pm$ & 48.98 & 2109.42 & 0.29 \\
\hline \multirow[t]{2}{*}{ G2 } & Selected & 167.7 & & 47.12 & 48.9 & 2380. & 06 \\
\hline & Cont & 174 & & 34 & 6 & 197 & 12 \\
\hline \multicolumn{2}{|l|}{ Overall mean } & & & & & & \\
\hline \multirow[t]{2}{*}{ G3 } & Sele & & & & & & \\
\hline & Cor & & & & & 195 & \\
\hline \multicolumn{2}{|l|}{ Overall mean } & & & 46.75 & & & \\
\hline \multicolumn{8}{|c|}{ ificances } \\
\hline \multicolumn{2}{|l|}{ ation (g) } & 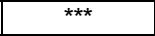 & & $\overline{\star \star \star \star}$ & *ћ & $\overline{\star \star \star \star *}$ & *ћ \\
\hline \multirow{2}{*}{\multicolumn{2}{|c|}{\begin{tabular}{|l|l} 
Line(L) \\
\end{tabular}}} & 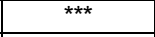 & ** & *夫 & 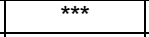 & $\star \star \star$ & 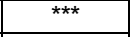 \\
\hline & & * & * & * & ** & * & * \\
\hline \multicolumn{8}{|c|}{$\begin{array}{l}\text { G1= First generation G2= Second generation G3=third generation }{ }^{*}=\text { significant at } 0.05 \\
{ }^{* *}=\text { significant at } 0.01 \text { ASM=Age at sexual maturity, BWSM=body weight at sexual } \\
\text { maturity, EN=egg number during the first } 90 \text { days of laying, EW=average egg weight } \\
\text { during the first } 90 \text { days of laying, EM=egg mass (first } 90 \text { days of laying) F.conv.= Feed } \\
\text { conversion (first } 90 \text { days of laying) }\end{array}$} \\
\hline
\end{tabular}

\section{Genetic parameter:}

Heritability:

The estimated $h^{2}$ for body weight at different ages for the selected and control lines are presented in Table (5). $\mathrm{H}^{2}$ for selected line and control line for most subsequent body weight at $(0,4,8$ and 12 weeks of age) were moderate (0. 29, $0.35,0.48$ and 0.21 ), respectively for selected line and $(0.26,0.37,0.53$ and 0.37$)$, respectively for control line. Generally, one can concluded that genetic selection at early ages may gave rapid improvement in growth of these local strain Abdel-Latif and El-Hammady (1992), Enab (2000), Kosba et al. (2002), Ghanem (2003), Abdel-Ghany (2006) and Balat et al.,(2008), who reported that heritability values of body weight at 4 weeks in local strains of chicken ranged from $(0.13$ to 0.66$)$.

The estimated of heritability $\left(h^{2}\right)$ were obtained according to sire variance component of egg production traits for selected and control lines are presented in Table (6), and they were in good agreement with that estimated by Abdou and Kolestad (1979), Enab (1991) and El-Wardany and Abdou (1993). 
Table (5): Heritability (diagonal), genetic correlation (above diagonal) and phenotypic correlation (below diagonal) between body weight traits for selected and control lines.

\begin{tabular}{|l|c|c|c|c|}
\hline \multirow{2}{*}{ trait } & Bw0 & Bw4 & Bw8 & Bw12 \\
\cline { 2 - 5 } & \multicolumn{4}{|c|}{ Selected line } \\
\hline Bw0 & $0.136 \pm 0.12$ & 0.297 & 0.168 & 0.226 \\
\hline Bw4 & 0.453 & $0.323 \pm 0.09$ & 0.895 & 0.713 \\
\hline Bw8 & 0.511 & 0.143 & $0.582 \pm 0.16$ & 0.337 \\
\hline \multicolumn{4}{|c|}{0.498} & 0.469 \\
\hline Bw0 & 0.387 & 0.192 & 0.242 & $0.614 \pm 0.14$ \\
\hline Bw4 & $0.161 \pm 0.08$ & $0.316 \pm 0.19$ & 0.811 & 0.187 \\
\hline Bw8 & 0.481 & 0.521 & $0.532 \pm 0.17$ & 0.371 \\
\hline Bw12 & 0.411 & 0.402 & 0.293 & $0.598 \pm 0.12$ \\
\hline
\end{tabular}

Table (6): Heritability (diagonal), genetic correlation (above diagonal) and phenotypic correlation (below diagonal) between egg production traits for selected and control lines.

\begin{tabular}{|c|c|c|c|c|c|c|}
\hline Traits & ASM & BWSM & EN & EW & EM & F.Conv. \\
\hline \multicolumn{7}{|c|}{ Selected line } \\
\hline ASM & $0.621 \pm 0.224$ & 0.364 & -0.392 & 0.079 & 0.331 & 0.211 \\
\hline BWSM & 0.311 & $0.415 \pm 0.223$ & 0.279 & 0.292 & 0.397 & 0.374 \\
\hline Egg number & 0.367 & 0.412 & $0.353 \pm 0.264$ & -0.315 & 0.798 & -0.241 \\
\hline Egg weight & 0.324 & 0.34 & -0.412 & $0.592 \pm 0.182$ & 0.297 & 0.312 \\
\hline Egg mass & 0.362 & 0.432 & 0.178 & 0.323 & $0.393 \pm 0.233$ & 0.185 \\
\hline $\begin{array}{l}\text { Feed } \\
\text { conversion }\end{array}$ & 0.019 & 0.386 & 0.137 & 0.351 & 0.295 & $0.372 \pm 0.320$ \\
\hline \multicolumn{7}{|c|}{ Control line } \\
\hline ASM & $0.492 \pm 0.214$ & 0.487 & -0.598 & 0.457 & -0.612 & 0.126 \\
\hline BWSM & 0.413 & $0.213 \pm 0.114$ & -0.079 & 0.574 & -0.112 & 0.345 \\
\hline Egg number & 0.289 & 0.493 & $0.382 \pm 0.119$ & -0.446 & 0.897 & -0.114 \\
\hline Egg weight & 0.398 & 0.678 & 0.712 & $0.321 \pm 0.114$ & -0.076 & 0.378 \\
\hline Egg mass & 0.312 & 0.546 & 0.234 & 0.298 & $0.365 \pm 0.191$ & 0.326 \\
\hline $\begin{array}{l}\text { Feed } \\
\text { conversion }\end{array}$ & 0.175 & 0.297 & 0.314 & 0.126 & 0.179 & $0.223 \pm 0.171$ \\
\hline
\end{tabular}

The $h^{2}$ estimates of age at sexual maturity (ASM) were high (0.62) and moderate (0.49) for selected and control lines, respectively. Result in the present study is higher than those reported by El-Full(2001),and Ghanem (2003)and agreement with those reported by Balat et al, (2008). The heritability estimates of age at sexual maturity (ASM)over two generations in Mandarh. The results reflect the possibility of improving egg production through selection for early sexually maturity birds. The $h^{2}$ estimates of body weight at sexual maturity (BWSM) was moderate $(0.41)$ for selected line and low $(0.21)$ for the control line. The results agreement with those reported by Kosba et al,(2006). The $\mathrm{h}^{2}$ estimates of egg number was moderate $(0.35$ and 0.38 ) in both lines, respectively. Similar estimates were found with Kosba et al, (2002), Younis and Abdel-Ghany (2004), Abdel-Ghany (2005), and Balat et al, (2008). While, Singh and Singh (1985) found high heritability values. The $\mathrm{h}^{2}$ estimates of egg weight were high for the selected line (0.59), while it was moderate for the control line (0.32). The results agreement with those reported by Kosba et al.(1997), Enab et al.(2000), and Balat et al.(2008). The 
$\mathrm{h}^{2}$ estimates of egg mass were moderate $(0.39$ and 0.36$)$ for both the selected line and the control lines, respectively. These values were agreement with those reported by Abdella (2006) and Balat et al. (2008). Concerning, feed conversion was moderate for the selected line (0.37), while it was low for control line. Generally, heritability estimates based on sire component were higher for the selected line than the control line. This result indicated that selection affected the heritability estimates as found by Kosba et al.(2002) and Balat et al. (2008) who reported that heritability increased by selection.

The heritability estimates and other parameters of population over many generations for body weight at the different ages studied, egg production traits and feed conversion of selective breeding are necessary for an understanding of the problems involved in the formulation of efficient breeding plans partial improved flocks Balat et al., 2008.

\section{Genetic correlations:}

Genetic correlation among body weight at the different ages for both selected and control lines were positive (Table 7). Moreover, low between BW at hatch and both BW4, BW8 and BW12, while that between BW4 and BW8 and BW12 weeks were high (0.89 and 0.71) for selected line and $(0.81$ and 0.69) for control line. Kosba et al., 2006 and Balat et al., 2008 found very low estimates of genetic correlation between BW at hatch and BW8.

Table (7): Genetic correlation between body weights, egg production traits for selected and control lines.

\begin{tabular}{|l|c|c|c|c|c|c|}
\hline \multirow{2}{*}{$\begin{array}{l}\text { Traits } \\
\text { Line }\end{array}$} & \multicolumn{3}{|c|}{ Selected line } & \multicolumn{3}{c|}{ Control line } \\
\cline { 2 - 7 } & BW4 & BW8 & BW12 & BW4 & BW8 & BW12 \\
\hline Age at sexual maturity & -0.361 & -0.312 & -0.232 & 0.063 & 0.031 & 0.124 \\
\hline Body weight at sexual maturity & 0.593 & 0.298 & 0.236 & 0.687 & 0.836 & 0.546 \\
\hline Egg number & 0.211 & -0.354 & -0.246 & 0.261 & -0.313 & -0.215 \\
\hline Egg weight & 0.235 & 0.087 & 0.014 & -0.316 & -0.567 & -0.412 \\
\hline Egg mass & -0.163 & -0.021 & 0.039 & 0.084 & 0.184 & 0.034 \\
\hline Feed conversion & 0.124 & -0.106 & -0.169 & 0.144 & -0.111 & -0.107 \\
\hline
\end{tabular}

The genetic correlations estimates among egg production traits are presented in (Table 7). Genetic correlation estimates for age at sexual maturity were positive with all egg production traits studied except with egg number it was negative the selected line. There were positive and relatively low estimates of genetic correlation between ASM and egg weight and feed conversion, also there were positive and relative low estimates of genetic correlation between BWSM and EN and EW, and moderate with EM and Feed conversion. Estimates of genetic correlation was negative and moderate between egg number and egg weight $(-0.31)$, while it was high with egg mass (0.79). There results agreement with those reported by Balat et al., (2008).

The control line, the genetic correlation of ASM were positive with BWSM (0.48) and (0.45) with EW, while they were negative and high (-0.59) with EN and EM (-0.61), there were positive and relatively low estimates of genetic correlation between ASM with feed conversion (0.12). Estimates of rg between BWSM with both EN and EM traits were negative and low, while it 
was positive and high with EW and moderate with feed conversion. The rg was negative and moderate between EN with EW (-0.44), high with EM and negative and low with feed conversion $(-0.24)$. The rg was negative and low between EW with EM (-0.076) and positive and moderate with feed conversion (0.37).Generally, the highly genetic correlation between any two traits, indicated that selection in trait improve the other trait indirect.

\section{Phenotypic correlations:}

The phenotypic correlation among body weight traits for selected and control lines for Mandarah strain are presented in Table (8). The rp estimates of both the selected and control lines were positive and moderate among BW traits studied except rp between BW4 and BW8 for the selected line which had low estimated $(0.14)$.

Table (8): phenotypic correlation between body weights, egg production traits for selected and control lines.

\begin{tabular}{|l|c|c|c|c|c|c|}
\hline \multirow{2}{*}{$\begin{array}{l}\text { Traits } \\
\text { Line }\end{array}$} & \multicolumn{3}{|c|}{ Selected line } & \multicolumn{3}{c|}{ Control line } \\
\cline { 2 - 7 } & BW4 & BW8 & BW12 & BW4 & BW8 & BW12 \\
\hline Age at sexual maturity & 0.261 & 0.492 & 0.298 & 0.374 & 0.414 & 0.325 \\
\hline Body weight at sexual maturity & 0.211 & 0.346 & 0.313 & 0.276 & 0.373 & 0.336 \\
\hline Egg number & 0.312 & 0.497 & 0.342 & 0.283 & 0.397 & 0.213 \\
\hline Egg weight & 0.389 & 0.501 & 0.376 & 0.489 & 0.549 & 0.514 \\
\hline Egg mass & 0.343 & 0.456 & 0.298 & 0.302 & 0.346 & 0.312 \\
\hline Feed conversion & 0.114 & 0.291 & 0.178 & 0.110 & 0.261 & 0.231 \\
\hline
\end{tabular}

The phenotypic correlation $\mathrm{rp}$ among all egg production traits were positive and the range is between low and moderate estimates (0.019-0.432) for the selected line, Table (8). Concerning the control line, result showed positive and moderate rp between ASM with BWSM, EN, EW and EM $(0.413$, $0.289,0.398$ and 0.312 ), respectively, while it was low between ASM with feed conversion (0.175), Table (8). Estimates of rp were positive and moderate between BWSM and both of EN, EW, and EM and feed conversion $(0.493,0.678,0.546$ and 0.297$)$, respectively, Egg number had positive and high rp (0.712) with EW, while it was moderate with EM and feed conversion. In addition, rp was positive and moderate between EW with EM (0.298), and low with feed conversion. These results are in agreement with those reported by Enab et al., (2001), Abdel-Ghany (2005) and Balat et al.,(2008).and different results were found by Sheble et al., (1991), Francesch et al., (1997), Enab et al.,(2001), Abdel-Ghany (2005), Abdella (2006), Enayat, (2006), Saleh et al., (2006)and Balat et al.,(2008).

\section{Genetic correlation among egg production and body weight trait:}

The genetic correlation among egg production and body weight traits for selected and control lines are presented in (Table 8). In the selected line, genetic correlation between BW4 and body weight at sexual maturity was positive and high (0.59), while estimates were moderate with EN (0.21) and EW (0.23) and positive and low between BW4 with feed conversion. The $\mathrm{rg}$ estimates were negative and moderate with age at sexual maturity $(-0.36)$ and low with egg mass $(-0.16)$. Concerning $\mathrm{rg}$ between BW8 and egg production traits, all estimates were low and moderate, genetic correlation between BW8 and body weight at sexual maturity was positive and moderate 
(0.29), positive and low with egg weight and feed conversion $(0.087,0.106)$. The $\mathrm{rg}$ estimates were negative and moderate with age at sexual maturity and egg number $(-0.31$ and -0.35$)$, genetic correlation between BW12 and body weight at sexual maturity was positive and moderate (0.23), and positive and low with egg weight, egg mass and feed conversion (0.014, 0.039 and 0.169 ), respectively, and

the $\mathrm{rg}$ were negative and moderate with age at sexual maturity and egg number $(-0.23$ and -0.24$)$. Concerning for control line, genetic correlation between BW4 and body weight at sexual maturity was positive and high (0.68), while estimates were moderate with EN (0.26) and positive and low between BW4 with age at sexual maturity, egg mass and feed conversion $(0.063,0.084$ and 0.144$)$, while estimates were negative and moderate with EW(-0.316). Concerning rg between BW8 and BW12 with body weight at sexual maturity was positive and high $(0.83$ and 0.54$)$, while with age at sexual maturity, egg mass and feed conversion and negative with egg number and egg weight. Balat et al., (2008) found the genetic correlation between egg production and body weight traits showed a different genetic pattern in both selected and control lines. It could be concluded that selection for increased egg number during the first 90 days of laying in Mandarah strain decreased body weight and growth rate at different age.

Phenotypic correlations among egg production and body weight traits:

The estimates of phenotypic correlation $\mathrm{rP}$ among egg production and body weight traits are presented in Table 8 . Results showed positive and moderate $\mathrm{rP}$ values between BW4 and all egg production traits studied for both the selected and control lines except that with feed conversion for two lines which had low values (0.11). Concerning rP between BW8 and BW12 with egg production there were positive and moderate with all egg production traits studied for both the selected and control lines. In general, positive genetic and phenotypic correlations were found between body weight at 12 weeks of age with body weight at sexual maturity, egg weight and egg mass, while was negative value with age at sexual maturity, egg number and feed conversion for egg production.

\section{Realized correlated response:}

Table (9) shows the cumulative realized correlated response for body weight was negative at BW8 for male (-21.24) and positive for female (76.24), and body weight was negative at BW12 for two sex( $-59.87,-75.62)$, but at BW0 and BW4 was positive $(1.23,20.27)$. These results of body weight are agreement with those obtained at different ages by Abdel-Halim (1999); ElTahawy (2000); Kosba et al. (2002); abdel-Ghany (2006) and Balat et al. (2008).

Table (10) shows the realized correlated responses of age at sexual maturity, body weight and egg production traits as result of selection for increase egg number during the first 90 days of laying. Negative correlated responses with age at sexual maturity were noticed (-8.06days), body weight at sexual maturity $(-58.10 \mathrm{~g})$, average egg weight in the first 90 days of age $(-0.47 \mathrm{~g})$. Similar results were reported by Enab (1982), El Wardany et al., (1992) and Yonis and Abd El Ghany (2004). Selection for increase egg number during the first 90 days of laying casued improving egg mass and 
feed conversion ,while realized correlated responses of egg mass during the first 90 days of laying , (232.7), Realized correlated responses of feed conversion were (0.17).El- Tahawy (2000) reports similar values for more of the previous relationships.

Table (9): Realized correlated response for growth traits in selected line by sex after two generations.

\begin{tabular}{|c|c|c|c|c|c|c|c|c|c|}
\hline \multirow[t]{3}{*}{ Traits } & \multicolumn{9}{|c|}{ Realized response } \\
\hline & \multicolumn{3}{|c|}{ Male } & \multicolumn{3}{|c|}{ Female } & \multicolumn{3}{|c|}{ Comb.Sex } \\
\hline & G1 & G2 & Cumulative & G1 & G2 & Cumulative & G1 & G2 & Cumulative \\
\hline BW0 & & & & & & & 1.05 & 0.18 & 1.23 \\
\hline BW4 & & & & & & & 14.48 & 5.79 & 20.27 \\
\hline BW8 & -27.99 & 6.75 & -21.24 & 0.33 & 75.91 & 76.24 & & & \\
\hline BW12 & -15.87 & -44.00 & -59.87 & -30.56 & -45.06 & -75.62 & & & \\
\hline $\operatorname{Gr}(0-4)$ & & & & & & & 1.26 & 0.42 & 1.68 \\
\hline $\operatorname{Gr}(4-8)$ & -15.85 & -2.66 & -18.51 & -6.07 & -12.49 & -18.56 & & & \\
\hline $\operatorname{Gr}(0-8)$ & 2.37 & 0.75 & 3.12 & 1.76 & 0.40 & 2.16 & & & \\
\hline $\operatorname{Gr}(8-12)$ & 2.88 & 5.36 & 8.24 & 4.89 & -0.57 & 4.32 & & & \\
\hline $\begin{array}{l}\text { G1 = First } \\
\text { weeks) }\end{array}$ & $\begin{array}{l}\text { enera } \\
\text { Gr(4-8 }\end{array}$ & & & ere & ion G & $\begin{array}{l}r(0-4)=g r \\
\text { s) }\end{array}$ & $\begin{array}{l}\text { vth rat } \\
\text { r(8-12) } \\
\text { ks) }\end{array}$ & & $\begin{array}{l}\text { ( hatch }-4 \\
\text { hate during } \\
\text { dy weight at }\end{array}$ \\
\hline
\end{tabular}

Table (10): Realized response for unselected traits in selected line by generation in egg production.

\begin{tabular}{|l|c|c|c|}
\hline \multirow{2}{*}{ Traits } & \multicolumn{3}{c|}{ Realized response } \\
\cline { 2 - 4 } & Generation 2 & Generation 3 & Cumulative \\
\hline Age at sexual maturity (day) & -0.94 & -7.12 & -8.06 \\
\hline Body weight at sexual maturity (g) & -42.07 & -16.03 & -58.10 \\
\hline Egg number at the first 90 days (egg) & 0.09 & 3.10 & 3.19 \\
\hline Average egg weight at the first 90 days (g) & -0.34 & -0.13 & -0.47 \\
\hline Egg mass the first 90 days (g) & 43.0 & 189.7 & 232.7 \\
\hline Feed conversation the first 90 days (g/g) & 0.33 & -0.19 & 0.17 \\
\hline
\end{tabular}

In general, the results of the present selection experiment that selection for increased egg number during the first 90 days of laying in Mandarah strain decreased body weight and growth rate at different age. Heritability estimates based on sire component were higher for the selected line than the control one, which indicated that selection affected the heritability estimates.

\section{REFERENCES}

Abd-Alla, M.A.H. (1997). Independent culling levels selection for improving body weight and feed conversion in chicken. M.Sc. Thesis, Fac. Of Agric., Alex. Univ., Egypt.

Abdella, M.M.M. (2006). Heritabilities and genetic correlation of feed efficiency and some egg production traits in Baheij chickens strain. M.Sc. Thesis, Fac. of Agric., (Saba Basha) Alex. Univ., Egypt.

Abdel-Gawad,E.M., (1981). Mandarah,a new breed of chickens. Egypt Poult. Sci. 1: 16-22.

Abd El-Ghany, F.A., (2005). Selection for improving some economic traits in developed Inshas chickens strain.Journal of productivity and development, volume 10, no. (2); 195-210. 
Abd El-Ghany, F.A., (2006). Genetic studies for growth traits in Inshas strain. J. Agric. Sci. Mansoura Univ., 31 (2): 1301-1313.

Abdel-Latif, M.A. and H.Hammady (1992). Heritability of some egg production and egg quality traits in Dandarawi chickens. Egypt Poult.Sci., 12:751764.

Abd El-Halim, H.A. (1999).Selection and genetic analysis of some meat and egg production traits in local chickens. M.Sc. Thesis, Fac. of Agric., Alex. Univ., Egypt.

Abdou, A.M. (2006). Effect of selection for 8-week body weight of male broiler parents on the performance and genetic parameters of their progeny. Egypt. Poult. Sci 26(111) 1217-1240.

Abdou, F.H. and Kolsted, N. (1979). Genetic analysis of a control population of White Leghorn hens.Agric., Univ. of Norway. Dep., of Poult. And Fur Anim. Sci. Report No.63.

Abdou, A.M.; and A.A., Enab(1994). A comparison between the efficiencies of restricted selection indices with different leveles of restriction in selection breeding programs for laying hens. The second Sci. Conf. on Poult. 12-12 Sep. Kafr El-Sheih, Egypt.

Ali, O.M. (1992). Selection for improving egg.- mass in Alexandria strain of chickens. M.Sc. Thesis, Fac of Agric., Alex. Univ., Egypt.

Balat, Magda, M.; Nazla, Y; Abou El-Ella; O. M. Aly, and H.,Ghanem (2008). Selection for improving egg production in Mandarah chickens to maximize the net income. 2. correlated responses, heritability, genetic and phenotypic correlation among egg production and growth traits. Egypt. Poult. Sci.,Vol (28) (11) : 367-382.

Becker, W.A. (1985). Manual of quantitative genetics (4th ed). Academic Enter pises, Pullman, Washington, U.S.A.

Brody, S. (1945). Bioenergetics and growth. Reinhold pup. Crop. N.Y., U.S.A.

Chen, C.F. and M. Tixier-Boichard (2003). Correlated responses to long-term selection for clutch length in dwarf brown-egg layers carrying or not carrying the naked neck gene. Poult. Sci. 82(5):709-20.

Duncan, D.B. (1955). Multiple range and multiple F test. Biometrics 11:1-42.

El-Full, Ensaf, A. (2001). Genetic and phenotypic parameters of egg production in relation to certain plasma constituents in Dandarawi and Golden Montazah hens. Egypt. Poult. Sci. 21: 765-793.

El-Tahawy, W.S. (2000). Genetically improvement of some productive and reproductive traits in local chicken. M. Sc. Thesis. Fac. of Agric., Alex. Univ., Egypt

El-Wardany, A.M.and Abdou, F.H. (1993). Genetic analysis of two strains of Norfa chickens under selection for egg number or size.2-Expected realized correlated respo0nse. Minufia J. Agric. Res. Vol.,18(1): 241256.

El-Wardany, A.M.; Soltan , M.E.;and Abdou, F.H. (1992). Correlated selection respons to selection for some egg production traits in Norfa chickens. Menofiya J. Agric. Res. Vol., $17(4): 1833$ - 63.

Enab, A.A.(1982).Genetic analysis of some economic traits in chickens.M.Sc. Thesis, Fac. Of Agric., Minufiya Univ. Egypt.

Enab, A.A.(1991). The use of different selection indices for the improvement of some economic traits in laying hens. Ph.D.Thesis Minifyia Univ.

Enab, A.A. (2000). Genetic progress achieved in residual feed consumption after two generations of selection in Norfa layer chickens. Egypt. Poult. Sci 20: 209-220.

Enab, A.A.; N., Kolstad; and F.H., Abdou (2001). Multi-source multi-trait selection indices for maximizing genetic improvement of laying hens. Egypt. Poult. Sci 21: 277-290. 
Enayat, A.H., (2006). Selection for increasing egg production characters in two local strains of chickens. M.Sc.Thesis, Fac. Of Agric., Kafr ElSheikh Tanta Univ. Egypt.

Francesch, A; J. Estany; L. Alfonso and M. Iglesias (1997). Genetic parameters for egg number, egg weight, and eggshell color in three Catalan poultry breeds. Poult Sci. 76(12):1627-31.

Ghanem, Hanan, H. (2003). Selection for low yolk cholesterol and its correlated response on some economic traits in local laying hens strain. Ph.D. Thesis, Fac. of Agric., Alex. Univ., Egypt.

Guill, R.A.; and K.W., Washburn (1974). Genetic changes in efficiency of feed utilization of chickens maintaining body weight constant. Poult. Sci. , 53:1146-1154.

Hartmann, C.; E., Strandberg; L., Rydhmer; K., Jahansson (2003). Genetic relation of yolk proportion and chick weight with production traits in a White Leghorn line. Br. Poult. Sci. 44(2):186-191.

Harvey, W.R. (1990). Mixed Model Least- Square and Maximum Likelihood Computer Program. Ohio State. Uni. Columbus. Ohio, U.S.A.

Kinny. T.B. (1969) A summary of reported estimates of heritabilities and of genetic and phenotypic correlations for traits of chickens. Agricultural Handbook Number363. Agricultural Research Service, USDA, Washington, DC.

Kosba, M.A.; G.E., Hassan; M., Bahi El-Deen; and Hanan, H. Ghanem (1997). Selection and correlated response for age at sexual maturity in Alexandria chickens. the 2nd Hungarian. Egyptian Conf. Godollo 16-19 Sept. Pages 179-188.

Kosba, M.A.; M. Farghaly; M., Bahie El-Deen; and H.A., Abd-El-Halim (2002). Selection and genetic analysis of some egg production traits in local chickens. Egypt. Poult. Sci. 22: 681-696.

Kosba, M.A.; M., Farghaly; M., Bahie El-Deen; and M.M., Iraqi; A.F.M., ElLaban; and H.A., Abd-El-Halim (2006). Genetic trends and evaluation for productive traits in Alexandria chickens. Egypt. Poult. Sci. 26 (IV): 1497-1513.

Saleh, K. M.; N.S., Isshak; T.H., Mahmoud; and A.A., Debess ( 2002). Selection and correlated response for some production traits in Baheij strain. Egypt. Poult. Sci. 22 (III): 653-664

Saleh, K. M.;et al., (2006).Selection and correlated response for egg production traits in Inshas and Silver Montazah strains of chickens.Egypt Sci.Poult. 26, (11): 749-770.

SAS Institute (1988). User, s Guide Statistics. SAS Institute INC., Cary, NC, USA.

Shebl, M.K. (1986). Response to individual and index selection for some economic traits in Alexandria chickens. Ph.D.Thesis, Fac.of Agric., Alex. Univ. Egypt.

Shebl, M.K.; M.A., Soltan; M., Kosba; and F.H., Abdou (1991). Genotype environment interactions for growth and reproductive traits in Norfa chickens. Monoufia J. Agric. Res., 16:1439-1455.

Singh, R.P; R.J., Kumar; and D.S., Balaine (1986). Genetic and phenotypic of production traits in a population of White Leghorn under selection. Ind. J. Poult. Sci. 21:1-4.

Soltan, M.E. (1991). Direct response in egg production from selection on early part records and correlated response in some economic traits a result of this selection in Sinai (Bedouin) fowl. Minufiya J-Agric. Res. Vol . 16 (1) : 373-417. 
Tawfeek, M. J. (1988). Improvement of methods of early appreciation and selection of poultry according to a complex of indication. Ph. D. Thesis, Academic of Agriculture, Keive, USSR.

Younis, H. H.; and F.A., Abd EL-Ghany (2004). Direct and correlated response to selection for egg number in Silver Montazah chickens. Egypt. Poult. Sci. 24:701-718.

$$
\begin{aligned}
& \text { الأنتخاب لتحسين إ نتاج البيض فى دجاج المندرة لتعظيم صافى العائد : }
\end{aligned}
$$

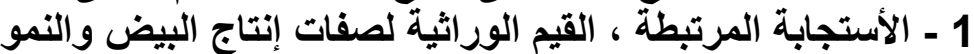

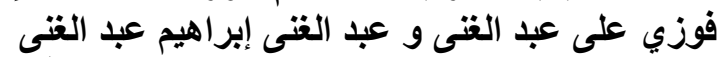

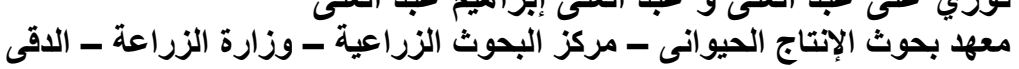

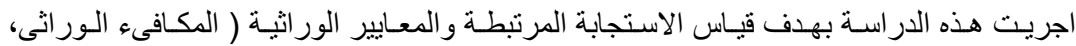

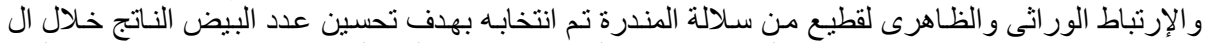

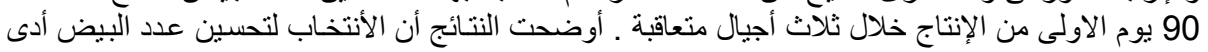

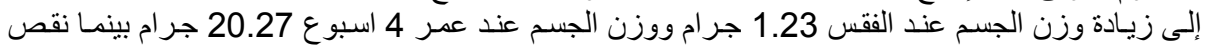

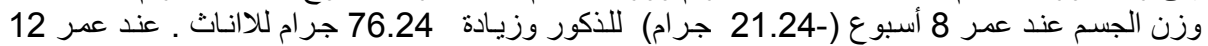

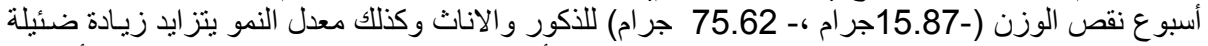

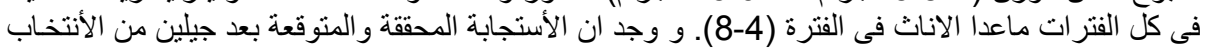

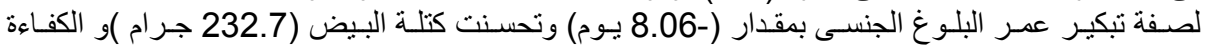

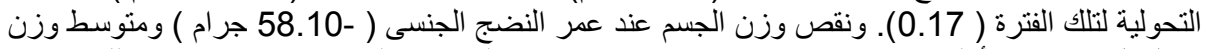

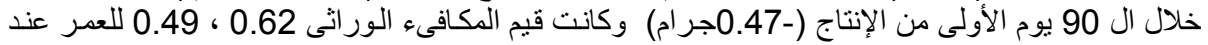

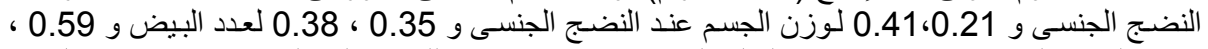

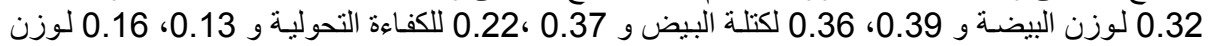

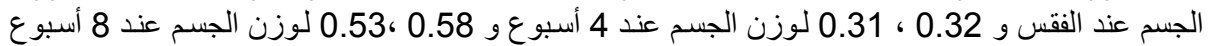

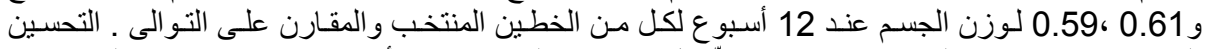

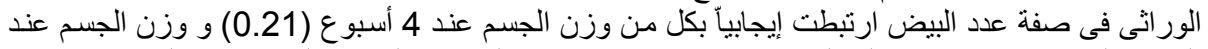

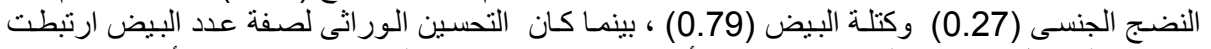

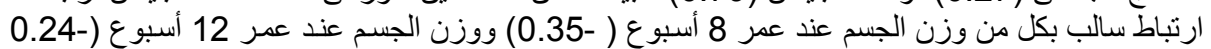

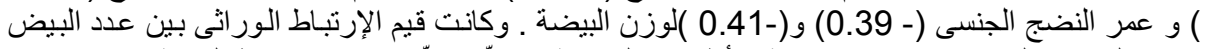

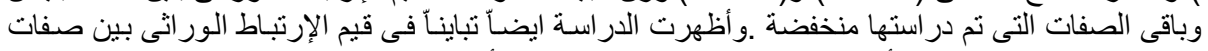

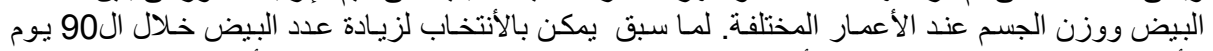

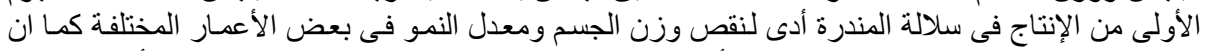

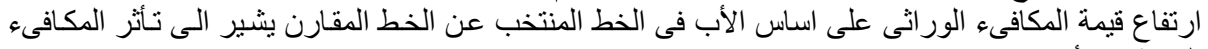

